\title{
Applications of template $A 3$ and value-stream mapping in process improvement: the case of building elevators installation
}

\author{
Aplicações do template A3 e do mapeamento de fluxo de valor na \\ melhoria de processos: o caso da instalação de elevadores \\ prediais
}

\author{
Gino Flávio Vieira ${ }^{1}$, James Manoel Guimarães Weiss ${ }^{2}$ [] \\ ${ }^{1}$ TK Elevator - TKE, São Paulo, SP, Brasil. E-mail: gino.vieira@tkelevator.com \\ ${ }^{2}$ Instituto de Pesquisas Tecnológicas do Estado de São Paulo - IPT, São Paulo, SP, Brasil. E-mail: jmgweiss@ipt.br
}

How to cite: Vieira, G. F., \& Weiss, J. M. G. (2021). Applications of template A3 and value-stream mapping in process improvement: the case of building elevators installation. Gestão \& Produção, 28(1) e4795. https://doi.org/10.1590/1806-9649.2020v28e4795

\begin{abstract}
This article explores the application of lean thinking concepts in the analysis and obtaining of significant process improvements in building elevators installations. Based on a pilot installation, planned to analyze the installation processes of an elevator manufacturer, the authors compared two similar elevator installations. In one of them, they applied various lean thinking concepts and tools, with particular emphasis on template $\mathrm{A} 3$ and value stream mapping (VSM). This pilot installation planning was also developed based on the recommendations for efficient project management, structured by the Project Management Institute (PMI). The application of the template $\mathrm{A} 3$ and the value stream mapping to the installation of one of the elevators resulted in increased productivity, reduced installation times, and increased final quality of the product installed.
\end{abstract}

Keywords: Elevators; Value-stream mapping; VSM; Lean production; Project management; Process improvement.

Resumo: Este artigo explora a aplicação dos conceitos do Pensamento Enxuto (Lean Thinking) na análise e obtenção de melhorias significativas em processos de instalação de elevadores prediais. Com base em um projeto piloto, planejado para analisar a eficácia dos processos de instalação de um fabricante de elevadores, os autores compararam duas instalações de elevadores semelhantes, sendo que em uma delas, foram aplicados os diversos conceitos e ferramentas de análise do Pensamento Enxuto, com particular ênfase no template A3 e no mapeamento de fluxo de valor (MFV). O planejamento desse projeto piloto foi desenvolvido com base nas recomendações para a gestão eficiente de projetos, estruturadas pelo Project Management Institute (PMI). A aplicação do template A3 e do MFV à instalação de um dos elevadores resultou em aumento na produtividade, redução dos tempos de instalação e aumento da qualidade final do produto instalado.

Palavras-chave: Elevadores; Mapeamento do fluxo de valor; MFV; Produção enxuta; Gestão de projetos; Melhoria de processos.

Received Apr. 21, 2018 - Accepted Jan. 16, 2019

Financial support: None. 


\section{Introduction}

The production of elevators is a mature industrial activity. However, many incremental innovations have been occurring over time in order to reduce energy costs, automate operation and minimize building space occupation of these machines. In this context, new complex and more efficient designs have been introduced in the market by the world's leading elevator manufacturers (AECweb, 2018; Agnese, 2016; AlKodmany, 2015; Fischetti, 2009; Tetlow, 2007).

Elevators are made to order, according to the rating speed and maximum load capacity specifications. They consist in various mechanical structures, driven by electric motors equipped with electronic control systems. There are three main mechanical parts in an elevator: traction machine, cabin and counterweight. The traction machine is installed in the top of the cabin or in a machine room located at the top of the shaft, where the lift moves. The traction machine is composed of electric motor, main sheave and brake system. The counterweight is used to balance the weight of the cabin, being connected to the traction machine by means of a mobile pulley (Park \& Yang, 2010).

The final assembling and installation of the elevators are carried out inside the buildings by manufacturer's personnel. For that purpose, manufacturers send to the buildings all the tools, components and materials necessary to the installation. The elevator installations are usually performed in stages. In stage I, the mechanical components are installed: fixation of the rails to the structure of the building, positioning of the traction machine, traction of the steel cables and fixation of floor doors. In this step, the control panel of the elevator is also positioned and the electric connections of the cabin and of the traction machine are realized. In stage II the cabin, the floor doors actuation systems, the stage indicators and the call buttons panels are installed. In stage III the electromechanical adjustments of the equipment are realized. The evaluation of the final quality of the installation encompasses the fulfillment of the scope, deadline, cost and quality, according to the inspections and revisions forms. At the end of the installation, the customer acceptance letter is issued (Schindler, 2018; ThyssenKrupp, 2018).

The installation of elevators is, therefore, a process that combines standardized equipment and systems in highly customized installations, according to the specific characteristics of each building. There are important problems in the installation of elevators that can be solved by process improvement aiming to reduce delivery times, increase quality standards and increase productivity (Azambuja \& Formoso, 2003).

In general, the processes lead time of an elevator supplying is shown in Graph 1 below. However, there are variations in delivery times depending on the type of equipment to be installed. The contracting period is about 1 month, the executive design requires 1 to 3 months, the advice on pre-installation work varies from 1 to 2 months and the pre-installation process in the building takes from 4 to 7 months. An elevator installations process varies from one to three months. The total lead time for supplying and installing a contracted elevator can reach 10 months.

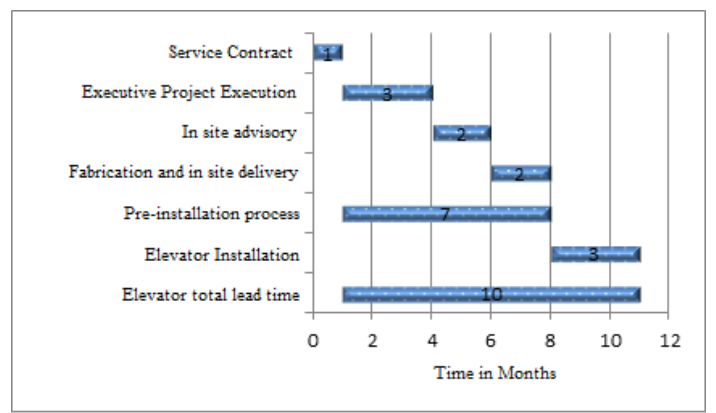

Graph 1. Lead time típico dos processos de fornecimento de elevadores. Source: Azambuja \& Formoso (2003). 
Due to its temporary nature, controlled costs and specific objectives, the elevators installations are usually managed as projects conducted by specific areas of the supplier company.

This article presents the results of an exploratory study covering the application of lean thinking and project management techniques in process analysis and improvement of assembling and installation of building elevators. Therefore, the authors compared the quality indicators of two different elevator installation of same model performed in the same building. The first installation adopted the conventional process of the elevator manufacturer. In the second installation, two techniques of lean thinking were applied to redesign the process: the analysis tool "template $A 3$ " and the value-stream mapping.

The Standard ISO 9001 recommends the application of technical norms and highly effective tools, as the checklists for process auditing (ABNT, 2015). The application of checklists intend to assist the work team in the execution of the right tasks, in the appropriate manner, trying to avoid rework and mistakes, enhancing the work team productivity and improving the production processes optimization (Gawande, 2011). Thereby, the assembling and installation processes followed the specific Brazilian technical norms for elevators (ABNT, 1999, 2007, 2008, 2012) and were assessed by inspections and reception forms (checklists) in all three assembling and installation stages.

\section{The Value-Stream Mapping (VSM)}

The Lean Thinking is defined as a business philosophy and strategy that aims to raise the client's satisfaction by the best use of the production resources. Thus, Lean Thinking is a way of specifying value and align at the best sequence the activities that generate value, perform these activities uninterruptedly, every time someone request it and perform better and better (Womack \& Jones, 1996; Marchwinski \& Shook, 2011).

The Lean Thinking approach started to be spread from the works of Womack et al. (1990), Shingo (1996) and Womack \& Jones (1996), inspiring the development of specific methods to assist its application in different productive processes.

The continuous search for excellence in business has been demanding a meticulous knowledge of all company's resources, mostly relative to the productive area, on which happens the value aggregation to the product. The processes mapping, elimination of losses and control by reliable indicators are essential factors to increase this knowledge and to give support to the decision making (Prates \& Bandeira, 2011).

The value-stream mapping (VSM) is a management tool designed to analyze the current state, or the stream map of a production process, and project a future state, aiming a major waste reduction when compared with the current state.

The value-stream mapping allows us to identify and remove the "waste" at different stages of a production system, enhancing its effectiveness. In fact, waste reduction provides the increase in productivity by development of leaner operations, making the bottlenecks identification easier, as well as other problems in the production stream. The value-stream mapping objective is to emphasize the waste sources and eliminate them by implementing a new value stream in a future state that can come true within a really short period of time (Rother \& Shook, 2012).

The value-stream is defined as all the production stages or a company's areas that aggregate value to a product or service. The value-stream comprises all the necessary actions to obtain a product or service (Rother \& Shook, 2012). Moreover, value-stream 
mapping is a simplified diagram that indicates all the stages involved in material and information stream necessary to produce a product or service, from the solicitation to the final delivery to the client (Marchwinski \& Shook, 2011).

The application of value-stream mapping (VSM) on processes improvement stimulates the relationship between people, the learning, the curiosity, the proactivity and the global understanding of materials and information stream, and thus facilitates and encourages actions planned on waste reduction. The method can be applied wideness in productive processes, on different industrial segments, allowing significant improvements regarding the readiness of delivered products and reduction of production lead time (Moreira \& Fernandes, 2001; Abdulmalek \& Rajgopal, 2007; Marcelino \& Weiss, 2009; Salgado et al., 2009).

The template $A 3$ is another lean thinking tool that can be used to synthesize the analysis a problem faced by a company on a single A3 size paper sheet. That allows a common vision, looking from the same perspective, to everyone facing the problem. Generally, the organization adjusts the template $A 3$ to fit in its particular requirements. The template $A 3$ guides the production teams to scientific thinking and problems roots analysis, at the same time that aligns individual interests and organizational departments' interests, encouraging fruitful dialogs and organizational learning. The template $A 3$ is a system that helps building up improvement opportunities based on practical experience. (Shook, 2009, 2014).

The middle-up-down management synthetize the implicit knowledge from the production frontline and make it explicit, aiming to incorporate new technologies. Regarding that matter, they can be considered the true "knowledge engineers", responsible for the company's knowledge creation (Nonaka \& Takeuchi, 1995).

Generally, companies aim to manage its change efforts by means of specific projects, undertaken to create new products, services or exclusive results. Therefore, necessary corporation's adaptation to market's new demands, usually are performed by means of temporary efforts, conducted based on the methodology suggested at the "project management knowledge guide - PMBOK guide" (Camargo Junior \& Pires, 2017).

The PMBOK guide's recommendations allow a management approach to all product process stages: conception (beginning), planning, acting, checking, corrective actions and closure (PMI, 2013).

The PMBOK sets basic knowledge areas that a project manager must master in order to achieve success in project administration. The PMBOK guide is not a methodology because it does not describe the how to do, yet it is a good guiding structure to project management best practices in which a company can base on to direct its specific methodology (Valle et al., 2010; Maximiano, 1988).

The PMBOK guide processes do not need to be explicitly considered in a project. They will unfold implicitly during the project course and will depend on each context and necessity. A project that do not strays from the initial planned budget, meets the schedule and makes delivers according to the stakeholders' requirements is considered a successful project. Other factors that evidence the project success are: making the scheduled deliveries; finishing within the approved time limit; acting within the approved budget; meeting the functional performance and quality specifications; achieving goals, objectives and purposes; fulfilling unrestrictedly stakeholders' expectations; not wasting resources; avoiding activities interruptions or losses. The project management team function it is to act, coordinate and support, on behavioral aspects, the operational team and external and internal clients during the entire project time duration (Vargas, 2007; Silva et al., 2017; Borges \& Carvalho, 2015; Rabechini Junior et al., 2011). 


\section{Methodology}

In order to establishing a suitable research method for each investigation, some aspects must be considered: (i) the contribution to answering the research's problem; (ii) the legitimacy along the scientific community; and (iii) the systematic procedures in research's conduction (Dresch et al., 2015).

There are some premises and restrictions orientated to choose a research methodology. Once identified the limitations by a literature review and developed the research questions, the researcher must analyze the possible approaches that may be applied, selecting the most appropriate, useful and effective one to tackle these issues or to deal with the studied problem into finding propositions and solutions (Dresch et al., 2015).

The objective of this research was to explore ways to obtaining improvement in the assembling and installation processes of ELEPROJ elevators (fictitious name of the studied company). The main delivery problems, identified by the company over time were difficulty to meet the scheduled deadlines and the attendance of quality standards in installations.

The choice for a case study methodology by the researches was because it established a reliable guide to face the involved issues.

A case study is an empirical investigation that analyzes a given phenomenon, mostly contemporaneous, inserted in a real life context, especially when the borders between the phenomenon and the context in which it is inserted are not clearly defined. The case studies can be classified according to its content and final objective as exploratory, explanatory or descriptive. As main tendency, the case study aims to enlighten the motivations behind the taking of one or more decisions, clarify how they were implemented and what were the results found (Yin, 2015).

Miguel (2007) proposes a structure and some recommendations for conduction of case studies in production engineering. The recommendations are briefly shown as follows:

a) Conceptual-Theoretical Structure Definition. At first, a conceptual theoretical referential of the research must be defined, based on a literature search and review on the subject. This referential must identify empirical or theoretical works that describe concepts to be empirically verified. From these concepts, propositions to be verified during the research can be set;

b) Case planning. The first planning stage is to choose the analysis unit, that is, the case or cases to be studied. A longitudinal case study aims at a real time investigation. The planning must consider the data access limitations and estimate the study completion time needed. After the case or cases selection, methods and techniques must be defined to data collection and analysis. Usually, it is considered interviews, documentary analysis, direct observation, surveys and factory floor visits to verify, in loco and/or in modus operandi, the phenomenon being studied. After, a research protocol must be prepared, not limited to a set of research questions, but containing general rules to the research conduction and procedures as well as indicating information sources (source types, individual, places, etc.);

c) Pilot test conduction. It is recommended the conduction of a pilot test before data collection. The objective of this test is to check the application of the protocol based procedures and verify the preliminary data quality and relevance regarding the research goals. From this pilot test, corrections and adjustments, necessary to enhance the research quality, must be done; 
d) Data collection. It is advised getting in touch with a senior executive that can authorize the research conduction, pointing the main interlocutors to be interviewed and that is able to solve any possible unexpected situation. Also, researcher's personal contacts are extremely useful to get access to the organization. The field notes are highly relevant to the data collection. Every impression, description or observation must be taken into consideration. Preferably, these records should be done the moment the events occur. If it cannot be immediate, must be done as soon as possible, to avoid any loss of important data. The events sequence must be planned (at the protocol), always considering an estimate period of time. The data collection can be considered finished when enough data is gathered to send the research question. Obviously, other aspects must be considered, as the time limitation due to admitted deadlines;

e) Data Analysis. Considering the multiple sources of evidence from the collected data, the researcher must produce a general case account. Generally, will be necessary to perform a data's reduction, so only essential information, with strong relationship with the objective and research's constructs, will be included in the analysis.

Considering the literature recommendations for conducting case studies, a pilot installation was proposed for the company aiming to explore ways to obtaining improvement in elevators assembling and installation methods. For that, it would be necessary to assess critically the installation management methods, the installation team composition, and the pre-installation programming and materials delivering in installation places. Consequently, the planning of the pilot installation was based on some lean thinking methods, never used before by the company in this way.

The pilot installation was conceived as an experiment, involving a company's installation team and applying some improvement methods proposed in a research protocol. This protocol was conceived by the authors and implemented by one of them, counting on company's projects management team and supported by the manager responsible for installations in the company.

The installation process analysis was based on two different but complementary approaches: lean thinking concepts (Ohno, 1997; Womack \& Jones, 1996; Womack et al., 2004; Rother \& Shook, 2012) and the project management guide MBOK (PMI, 2013). The lean thinking methods selected for this study were the template $\mathrm{A} 3$, to analyzing problems and improving processes, and the Value-Stream Mapping, to analyzing the installation lead times and the flow of material and information along the value stream (Rother \& Shook, 2012; Shook, 2014).

With a view to achieving the quality specifications in installations, the company uses checklists called Inspections and Revisions Forms (IRF), filled at the end of each installation stage. These forms contain a verifications list to assess the installation quality and its inherent tasks. Therefore, they verify the fulfillment of all installation stages or items according to the scheduled plan. The IRF forms are based on the technical norms ABNT NBR 16042/12, ABNT NBR 5410/04, ABNT NBR NM 207/99 and ABNT NBR NM 313/07, along with some company's quality criteria. These checklists were used to assess the pilot installation results.

Finally, this research can be classified as exploratory, because it involved new management methods for the company, was planned to clearly identifying process bottlenecks, intended to analyzing labor behaviors, and aimed contributing for future improvements in company's processes. It is also a single case study, involving a contemporary phenomenon within its real life context, because it proposed to analyze a single pilot installation, performed under controlled conditions and under researchers' supervision. 


\section{The assembly and installation pilot project}

\subsection{Conception and planning}

The pilot installation was conceived to compare the quality of a CKD (Completely Knock-Down) installation of two elevators of same model and same technical specifications, installed at the same time in the same building.

A project management team was proposed to manage and control the pilot installation. This team was formed by members from installation and engineering departments of the company. From the installation department, the coordinator, two supervisors and one administrative assistant were involved; from the engineering department, the engineering manager was involved. The team work was developed without prejudice to their respective usual activities at the company.

The knowledge fields proposed in PMBOK guide were utilized to conduct the factors analysis and planning that should be considered on this pilot installation. Hence, a project opening term (POT) was elaborated, according to the practice recommend by PMBOK. The project opening term was useful to demonstrate the study's feasibility and relevance to the stakeholders and obtain the company's permission to perform the pilot installation.

With the POT approved, the researchers prepared a research protocol that was submitted to the manager in charge of the company's local operations. This protocol passed five revisions until its final approval. One of the most relevant changes was the choice of the product to be studied. There was doubt among stakeholders whether the study would be about the process of installing a specific type of product or a product line. A specific type of product was chosen: the electromechanical elevator without machine room. This product is considered modern and sophisticated in relation to others and has a good commercial appeal because it does not occupy space in building roofing with a machine room.

Table 1 shows the technical characteristics of installed elevators. The building chosen for the installation had the local infrastructure finished and ready to receive the elevators installation, that is, with the pre-installation stage already completed.

The only difference between these two elevators was the door opening direction at the cabin entrance, which does not interfere with the assembling and installation process.

Table 1. Installed elevators technical main characteristics.

\begin{tabular}{ll}
\hline \multicolumn{2}{c}{ ELEVATORS' BASIC SPECIFICATIONS } \\
\hline \multirow{2}{*}{ Elevators' Characteristics } & Elevator A (Conventional Installation) \& \\
\cline { 2 - 2 } & Elevator B (Pilot Installation) \\
\hline Type & Eletromechanical without machine room \\
\hline Control & Vector Variating Voltage and Frequency (VVVF) \\
\hline Application & Commercial \\
\hline Cabin and Patio Doors Finishing & Coated in stainless steel \\
\hline Cabin and Patio Doors & Right Lateral Opening (RLO) $\rightarrow$ Elevator A; \\
\cline { 2 - 2 } & Left Lateral Opening (LLO) $\rightarrow$ Elevator B \\
\hline Capacity (People or kg) & 08 commuters or $600 \mathrm{~kg}$ \\
\hline Speed (m/min) or (m/s) & $60 \mathrm{~m} / \mathrm{min}$ or 01 $\mathrm{m} / \mathrm{s}$ \\
\hline Stops and Entrances & 02 \\
\hline Traction System & $2: 1$ \\
\hline Floors Denomination & 0 and 1 \\
\hline Cabin dimensions $(\mathrm{x} ; \mathrm{y})$ & $1200 \times 1400[\mathrm{~mm}]$ \\
\hline Available opening and available & $0,800[\mathrm{~m}]$ and $2,1[\mathrm{~m}]$ \\
\hline height &
\end{tabular}


Source: Studied Company.

\subsection{The template A3}

A template $\mathrm{A} 3$ for elevator installation was prepared aiming to bring simplicity, clarity and objectivity to the process analysis for the management team involved in the pilot installation. It was applied to assess the company's assembling and installation processes, identifying main quality issues and improvement possibilities.

The complete template A3 developed for planning the pilot installation is shown in the Annexe A, on two pages. The first page represents the template A3's left side, describing the current state (before the pilot installation). The second page represents the template A3's right side, describing the future state (with the improvements planned for the pilot installation).

The main problems stated and systematized on the template A3, were:

- Lack of synchronism at the equipment and material delivering to the installation site. Company's Material dispatch only happened twice a week;

- Low qualification of installation team;

- Inadequate IRF I,II and III filling by the assemblers;

- Assembly and installation processes could be simplified by transferring some activities to pre-installation stage;

- Replacement of missing or misguided parts used to take too long;

- Various problems regarding materials distribution at the installation site;

- There were some quality issues at the installation conclusion, with reflex on the final installation quality and necessity of rework.

Taking in account the pointed problems, the project management team decided to reconsider the installation procedures and employ workers with great experience and knowledge on elevators installation. Indeed, the installation and adjustments on the pilot installation were performed by experienced assemblers supervised by one professional specialized in electromechanical elevator "without machine room".

The main improvement possibilities identified with the help of template A3's were:

- Eliminate the material dispatch waiting time by monitoring and controlling the company's expedition, the shipping company and reception at installation place. Adopt daily dispatch of components and materials from the factory to the installation center;

- Allocate specialized and experienced assemblers in all stages of elevators assembling and installation. Designate a categorized supervisor to perform final adjustments on installed equipment;

- $\quad$ Allocate full time supervisors to monitoring the installation and compulsorily fill in the IRF I,II and III;

- Transfer the distribution, materials conference and plummet lines installation to pre installation (performed before elevator installation begins);

- Apply the same installation process utilized by the company's high performance teams;

- Check and distribute the materials and parts before starting installation;

- Avoid misguided parts by the supervisor's constant presence at the installation site and quickly replace missing parts by effective actions along the company; 
The template A3 provided important insights to the pilot installation.

In fact, at the pilot installation the materials delivery waiting time was eliminated. Previously, the mean waiting time for arrival of components at the installation place was 5 days.

The distribution, materials conference and plummet lines installation, previously performed at the first stage of the standard assembling, were anticipated to the preinstallation and performed before the beginning of elevator installation.

In order to avoid rework and enhance the installation quality a more qualified installation team was allocated, properly coordinated by the project management team. Each field professional designated to install and supervise the pilot installation had more than 25 years of experience on installation of elevators.

To control the performance properly and take corrective actions, when necessary, the forms IRF I, II and III were correctly filled.

Considering these actions, the stage I installation time was reduced from 21 to 17 days. Furthermore, the installation time at the stage II was reduced from 7 to 6 days.

\subsection{Value-stream mapping applied to elevators installation process}

The value-stream mapping (VSM) was applied oriented to compare the assembling and installation processes performed by the companies conventional procedure and by the new process, developed to the pilot installation.

The installation current state (company conventional process) map was prepared, as well as elevators installation future state map, considering the proposed process improvement, based on template A3.

The assembling and installation processes current state map is shown at Figure 1.

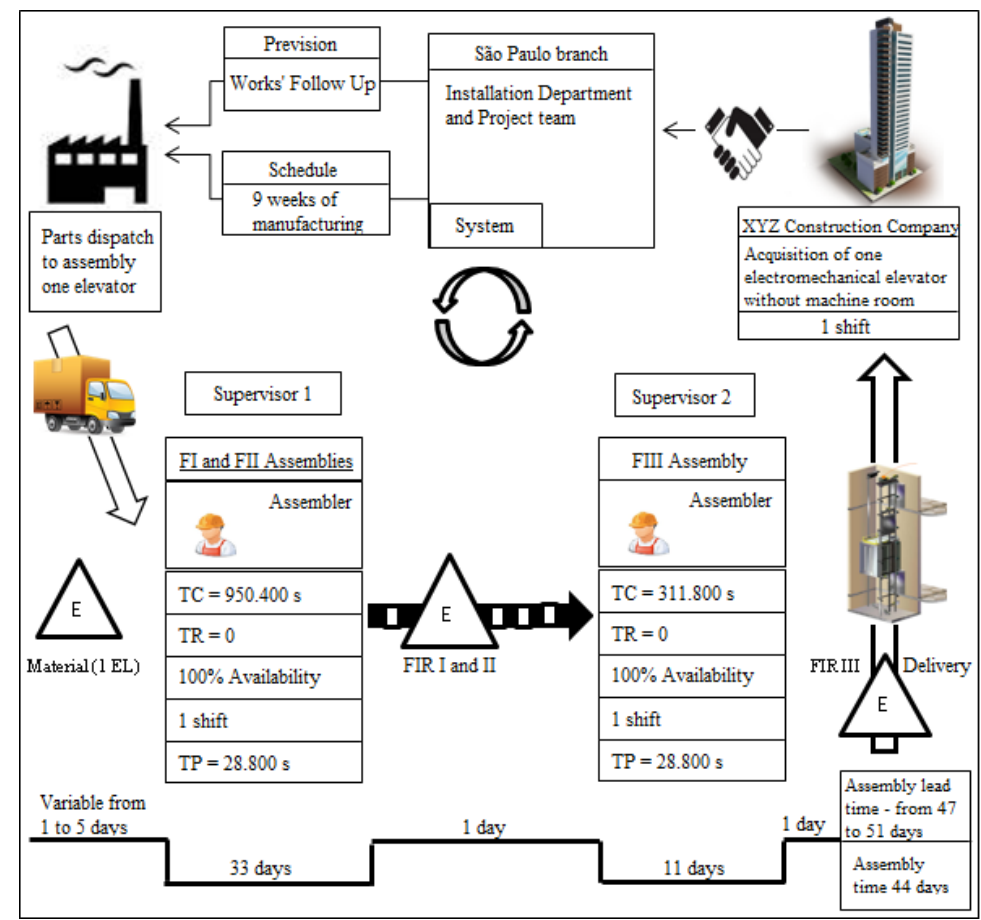

Figure 1. Current state map of elevators installation process. 
The top of the map indicates the previous stages to the installation process: the elevator purchasing order to the company, the product fabrication time planning and the fabricated product transportation to the installation place. The center of the map represents the components and materials transportation to the installation site, the elevator installation process starting, the assembling and installation stages and the finished product delivery to the construction company. The bottom of the map indicates the waiting time to materials dispatch to the installation site, the assembling and installation stages duration and the elevator installation total lead time

The present state VSM map indicates the potential improvements, as follows:

- Reduce the material time in stock. The material, once dispatched by the company, gets from 1 to 5 days waiting to be delivered to the site;

- Make sure the company sends $100 \%$ of the materials, and all the materials and parts to installation must be completely flawless;

- Effectively fill the inspection and revision forms (IRF) at each assembling stages closure. These were not being correctly filled by the assembling team;

- Focus on the assembling process improvement, because can be performed without intervals and stock, basically depending on workers labor and provided parts availability;

- Review the stages I and II assembling procedure, because it takes most of an elevator assembling time.

The future state map for the process applied to pilot installation planning, is shown in Figure 2. The main introduced improvements, derived from the template A3 and elevators installation process future state map joint analysis were:

- The assembling, distribution, materials conference and plummet lines installation stages were transferred to the pre installation, being performed before the installation process beginning;

- The elevators' materials and components dispatch waiting time was eliminated. The project management team made a deal with company and client, so there would not be materials stocked at the shipping company, waiting to be delivered to the site. Also, daily factory transportation to installation places was introduced, according to the planned installations schedule;

- The pilot elevator installation was performed by an experienced and specialized team;

- It was concluded that a quality inspections extra time would worth it, once it guarantees the assembling control and monitoring, as well as the final product delivery, without quality issues. The supervisor accompanied full time the installation and filled the inspection and revision forms (IRF I, II and III) at each assembling stages closure;

- As result of the process review, the stage I had its duration reduced from 21 days, at the previous state, to 17 days, at the future state. The stage II had its duration reduced from 07 to 06 days. 


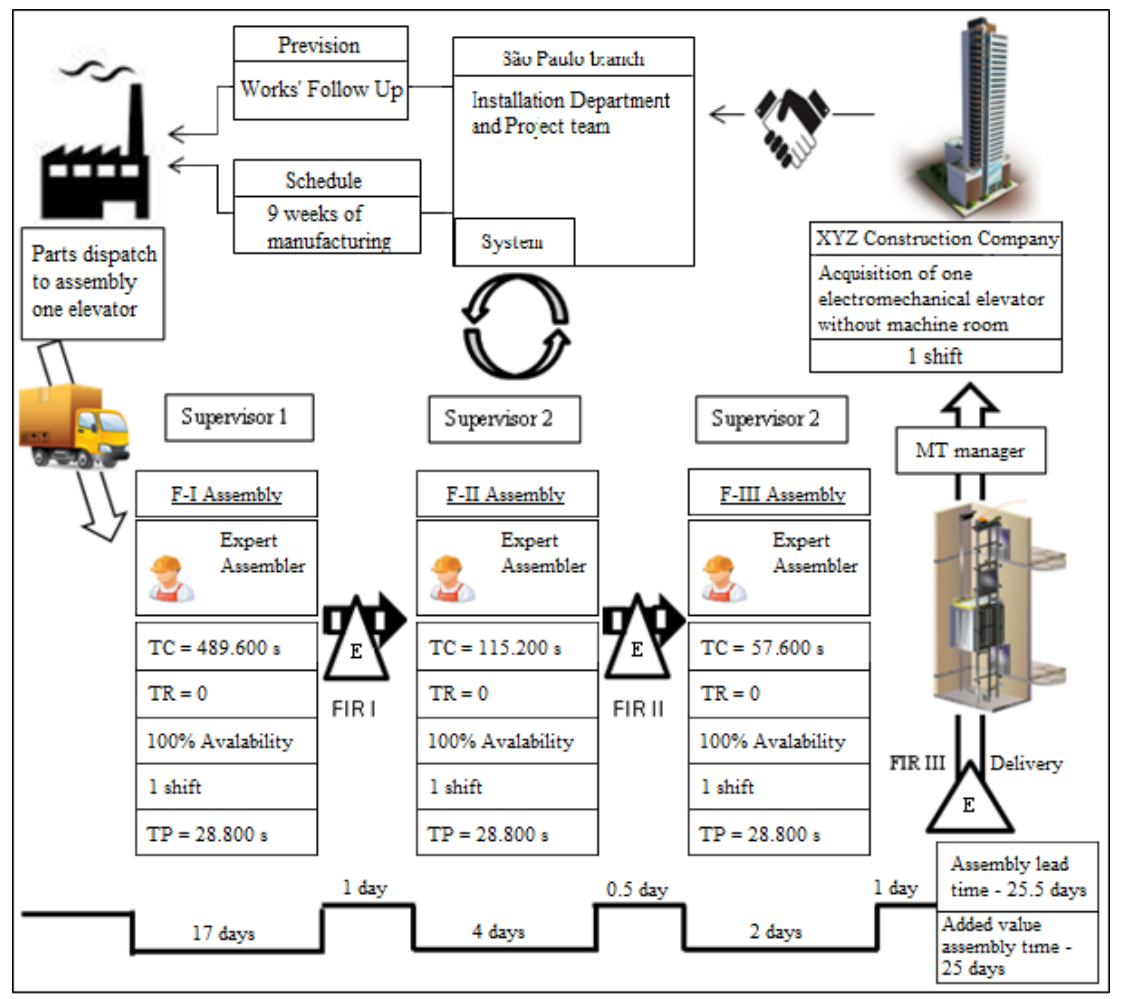

Figure 2. Future state map of elevators installation process.

\section{Results of pilot installation}

According to the study planning, the pilot elevator installation was performed by a capable installer team who knew the product very well, correctly followed the installation procedures and knew how to solve unexpected events effectively. Furthermore, they followed minutely the equipment assembling manual.

The installation process was coordinated by an experienced installation supervisor and monitored by the project management team. It was agreed that the supervisor would stay full time at the installation place to give real time orientations to installers ensuing a high quality standard to the installation. The supervisor passed daily information to the project management team, carried out work follow-up minutes with the client and checked all the items contained in the inspection and revision forms. He daily verified if the assemblers were following the schedule and the company's installation guide procedures.

At the end of each assembling and installation stage, the supervisor filled correctly the inspection and revision forms IRF I, II and III. This enabled immediate action by the management team in supporting the request for materials or interceding along with the client when necessary.

As result, the pilot installation was performed without quality issues and in a shorter time when compared to the conventional process. Table 2 summarizes the data obtained from the inspection and revision forms (IRF I, II and III) for both elevators installed.

The items considered in theses forms follow recommendations of the assembling and installation manual of the company and are based on current technical standards such as ABNT NM 207/99 and ABNT 16042/2012, which regulate the manufacture and installation of elevators in Brazil. 
Table 2. Comparison between installations according to the inspection and revision forms.

\begin{tabular}{|c|c|c|c|}
\hline ELEVATOR & IRF & $\begin{array}{l}\text { OCCURRENCES OBSERVED ON } \\
\text { THE FIELD }\end{array}$ & RESULT \\
\hline \multirow{3}{*}{ CONVENTIONAL } & I & $\begin{array}{l}\text { Not performed by the team due to } \\
\text { lack of work organization and "time" }\end{array}$ & \multirow{3}{*}{$\begin{array}{l}\text { There was rework to do. The } \\
\text { defects had to be solved by a } \\
\text { supervisor and a more } \\
\text { experienced assembler, after } \\
\text { installation conclusion. This meant } \\
\text { a delay in equipment delivery, } \\
\text { additional costs and lack of quality } \\
\text { perceived by client. }\end{array}$} \\
\hline & II & $\begin{array}{l}15 \text { quality issues appeared, affecting } \\
\text { equipment operational performance, } \\
\text { safety and final quality }\end{array}$ & \\
\hline & III & $\begin{array}{l}\text { Not performed by the team due to } \\
\text { lack of work organization and "time". }\end{array}$ & \\
\hline \multirow[b]{3}{*}{ PILOT PROJECT } & I & $\begin{array}{l}\text { The supervisor filled the IRF I in } \\
\text { detail for a careful analysis of the } \\
\text { assembling quality of the elevator }\end{array}$ & \multirow{3}{*}{$\begin{array}{l}\text { Elevator installed as planned, } \\
\text { with only } 2 \text { aesthetical issues at } \\
\text { the cabin, that were solved on } \\
\text { the same day by the assembling } \\
\text { team and the supervisor }\end{array}$} \\
\hline & II & No defects presented & \\
\hline & III & $\begin{array}{l}\text { It presented } 2 \text { aesthetical } \\
\text { observations on the final delivery, } \\
\text { but these were not considered } \\
\text { technical issues or affected the } \\
\text { product final quality }\end{array}$ & \\
\hline
\end{tabular}

Source: Studied Company.

It is noticeable the improvement on installation lead time after the changes in assembling and installation process. The assembling revision at stage $I$ and the capable installation team established a continuous flow into the process.

As can be observed at Graph 2, there was a reduction from 5 to zero days to the assembling materials (elevator parts and components) been delivering at the site. The waiting time for materials was eliminated by means of a continuous flux of materials dispatch from the company to site. There was also obtained a reduction by 4 days on the stage I assembling process. The reviewing of the process, including guides and machines positioning during pre-installation stage, permitted this time reduction.

The only stage that took longer in the pilot installation was the tests for filling the inspection and revision forms I and II (IRF I and II). But the tests duration for filling the inspection and revision form III (IRF III) did not take longer. In the final comparison between the two installations, the pilot installation was concluded 9.5 days earlier than the conventional installation.

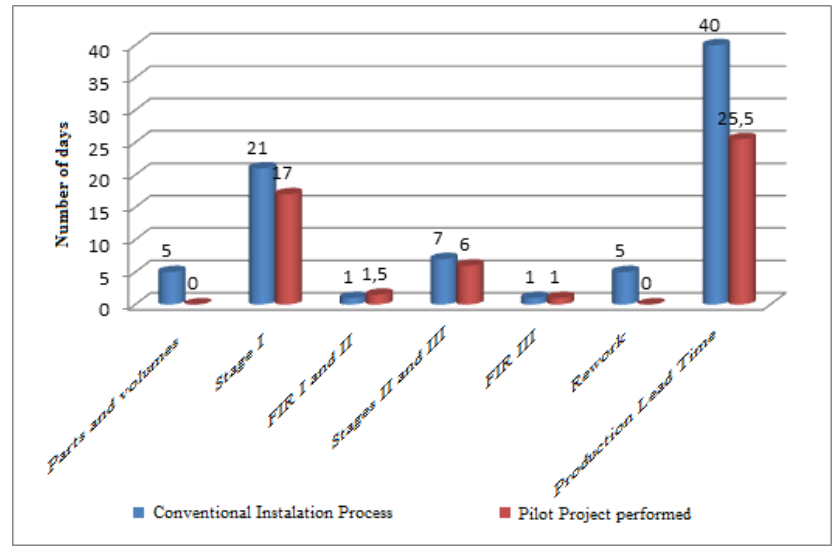

Graph 2. Comparison between the conventional installation and pilot installation lead times. 
On installation stages II and III, there was one day of time reduction in pilot installation. The duration of the final quality evaluation of the installation, by IRF III, was the same. However, several quality issues appeared in the $r$ conventional installation that could be avoided if observed at the stages I and II. The detected problems in the conventional installation demanded 5 additional days of rework, in order to correct them.

Comparing the pilot installation with the conventional installation it is observed a 14.5 days of total reduction on the installation lead time.

Observing elevator A installation (conventional installation - blue graph in Graph 2) is possible to verify the occurrence of rework and 5 additional days to solve problems after the elevator installation. On the other hand, in the elevator B installation (pilot installation - red graph) there was no need to rework.

Graph 3 compares both elevators installation costs, taking into account the involved workers hourly cost. The reference values considered in calculations were salary plus other charges of the team assigned for each installation. For comparison purposes, the total cost of the pilot installation is considered as $100 \%$.

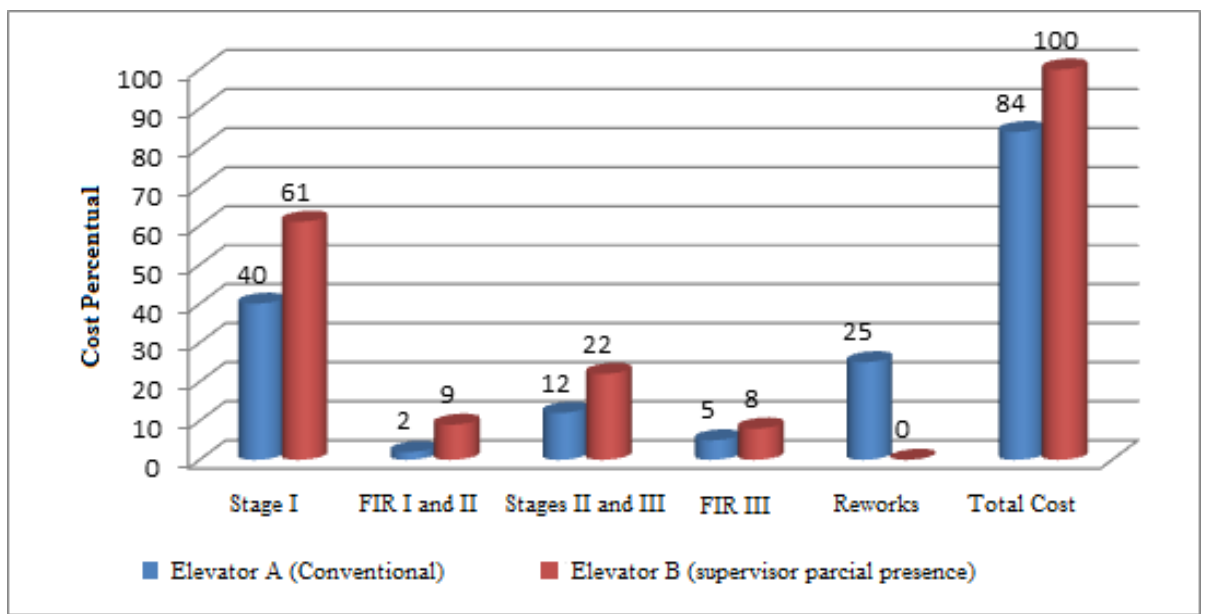

Graph 3. Comparison between the conventional installation (A) and pilot installation (B) costs.

For the reworks on the conventional installation, were consumed 5 work days of an experienced assembler and 2 work days of a supervisor, which represented $29.8 \%$ of the elevator A installation cost. The elevator B installation cost corresponds to the sum of 25.5 days of work of experienced assemblers plus 2.5 days of work of a supervisor. When compared to the conventional installation cost, reworks included, the elevator $B$ installation cost was $16 \%$ higher. Even though, the new installation process resulted in significant lead time and quality gains.

The project management team concluded that, for future installations, it will not be necessary to maintain a full time supervisor at the installation place, although it will be necessary a present and active support from the installation department and a highly qualified installation team in order to reduce total installation cost.

An elevator installation success depends on the punctuality of delivery, the budget observance, the achieving of a high quality standard and the client's satisfaction with the installed product.

The new installation process decreases considerably the risk of client complaint opening through the company's communication channels: CIS (Client Information 
Service), email and phone calls targeting the administration or direction. In some specific contractual cases (for example, contracts firmed with public agencies), there are contractual penalties involved in case of delivery delays. These penalties can reach $5 \%$ of the total elevator value, plus update interest per each day of delay.

Altogether, the new process gave a solution to company's recurrent problems of delivering delays and lack of quality in elevator installations. These issues used to cause several intangible costs, because involved several administrative actions and team mobilization inside the company to deal with the problems pointed by the clients.

\section{Discussion of results}

The pilot installation performed in this study effectively identified the major bottlenecks and the potential for improvements in electromechanical elevator installation process.

Although the costs related to the pilot installation were superior to the costs of a conventional process, it will be possible to improve productivity in the future by experience effect and new applications of lean thinking concepts.

The probability of obtaining improvements in the new installation process is very high, because the lead times are quite long and there is a low integration in different stages of the process, from the factory to the final installation at client's places.

The new process developed in this study includes the anticipation of some assembling stages for the pre-installation stage, the allocation of experienced and well qualified labor, an active management team, a proactive supervision conducting quality inspections and controlling installation methods, and a strict attention on completing the forms of inspections and revisions (IRFs). Furthermore, the logistic process regarding materials and components dispatched from the factory was also restructured. Now, the components are dispatched every day and there is a quality control to avoid problems of missing parts in deliveries.

Considering the results of this study, the company decided to adopt the new developed process in all installations of electromechanical elevators without a machine room. The expansion of these installation concepts to other products and areas of the company is also planned, but it will depend on a significant cultural change, as it will require a large contingent of qualified and well paid human resources.

These results are limited because they are based on a single case study drew on an experiment, performed on a basic product on a certain type of building. Therefore, it must be confirmed by other case studies on installation process of other types of elevators. However, the study started a cultural change inside the company making possible the implementation of some managerial practices that are essential to enhance quality and productivity on elevators installations.

\section{Conclusion}

The joint application of the template A3 and the value-stream mapping (VSM) made possible a detailed analysis of elevators installation process and the development of assertive actions oriented to quality enhancement, lead time reduction and clients' satisfaction. The pilot installation performed in this study did not need reworks, was concluded in a shorter period of time and provided higher client satisfaction when compared with a conventional installation. 
The body of knowledge on project management was applied to planning, executing, checking and performing the necessary corrections to this research. These practices provided to the project management team a privileged vision of the interactions between different departments and the various stages of an elevator installation process, imparting a new managerial dynamic to this process.

The final cost of the pilot installation was slightly superior to a conventional installation cost. Considering, however, that it was the first initiative to rationalize installation processes, it is probable that these costs can be reduced on future through the accumulated experience of assemblers and supervisors on the new process.

Based on the results of this study, the company decided to apply the recommendations and methodology developed in this research in all lines of elevators offered to the market.

\section{References}

Abdulmalek, F. A., \& Rajgopal, J. (2007). Analyzing the benefits of lean manufacturing and value stream mapping via simulation: a process sector case study. International Journal of Production Economics, 107(1), 223-236. http://dx.doi.org/10.1016/j.ijpe.2006.09.009.

Agnese, B. (2016, 1 November). Access granted. Architectural Record. Retrieved in 2018, October 25, from https://www.architecturalrecord.com/articles/12714-access-granted

Al-Kodmany, K. (2015). Tall buildings and elevators: a review of recent technological advances. Buildings, 5(3), 1070-1104. http://dx.doi.org/10.3390/buildings5031070.

Arquitetura, Construção e Engenharia - AECweb. (2018). Especificação de elevadores deve atender a NBR 5665. Retrieved in 2018, November 7, from

https://www.aecweb.com.br/cont/m/rev/especificacao-de-elevadores-deve-atender-a-nbr5665_8433_0_1

Associação Brasileira de Normas Técnicas - ABNT. (1999). NBR NM 207: elevadores elétricos de passageiros: requisitos de segurança para construção e instalação. Rio de Janeiro: ABNT. Retrieved in 2018, November 7, from https://www.target.com.br/produtos/normastecnicas/39605/nm207-elevadores-eletricos-de-passageiros-requisitos-de-seguranca-paraconstrucao-e-instalacao

Associação Brasileira de Normas Técnicas - ABNT. (2007). NBR NM 313: elevadores de passageiros: requisitos de segurança para construção e instalação: requisitos particulares para a acessibilidade das pessoas. Rio de Janeiro: ABNT. Retrieved in 2018, November 7 , from https://www.target.com.br/produtos/normas-tecnicas/40430/nm313-elevadores-depassageiros-requisitos-de-seguranca-para-construcao-e-instalacao-requisitos-particularesacessibilidade-incluindo-pessoas-com-deficiencia

Associação Brasileira de Normas Técnicas - ABNT. (2008). NBR 5410: instalações elétricas de baixa tensão. Rio de Janeiro: ABNT. Retrieved in 2018, November 7, from https://www.target.com.br/produtos/normas-tecnicas/28721/nbr5410-instalacoes-eletricasde-baixa-tensa

Associação Brasileira de Normas Técnicas - ABNT. (2012). NBR 16042: elevadores elétricos de passageiros: requisitos de segurança para construção e instalação de elevadores sem casa de máquinas. Rio de Janeiro: ABNT. Retrieved in 2018, November 7, from https://www.target.com.br/produtos/normas-tecnicas/42503/nbr16042-elevadores-eletricosde-passageiros-requisitos-de-seguranca-para-construcao-e-instalacao-de-elevadores-semcasa-de-maquinas

Associação Brasileira de Normas Técnicas - ABNT. (2015). NBR ISO 9001: 2015. Rio de Janeiro: ABNT. 66 p. 
Azambuja, M. M. B., \& Formoso, C. T. (2003). Diretrizes para a melhoria dos processos de projeto, aquisição e instalação de elevadores utilizando conceitos de gestão da cadeia de suprimentos. Ambiente Construído, 3(3), 77-94. Retrieved in 2018, November 7, from http://seer.ufrgs.br/index.php/ambienteconstruido/article/view/3496/1897

Borges, J. G., \& Carvalho, M. M. (2015). Critérios de sucesso em projetos: um estudo exploratório considerando a interferência das variáveis tipologia de projetos e stakeholders. Produção, 25(1), 232-253. http://dx.doi.org/10.1590/S010365132014005000019.

Camargo Junior, J. B., \& Pires, S. R. I. (2017). Sistematização da implementação de outsourcing logístico por meio de práticas de gestão de projetos. Gestão \& Produção, 24(2), 310-323. http://dx.doi.org/10.1590/0104-530x1287-15.

Dresch, A., Lacerda, D. P., \& Miguel, P. A. C. (2015). Uma análise distintiva entre o estudo de caso, a pesquisa-ação e a Design Science Research. Revista Brasileira de Gestão e Negócios, 17(56), 1116-1133. http://dx.doi.org/10.7819/rbgn.v17i56.2069.

Fischetti, M. (2009). New designs going up: working knowledge on elevators. Scientific American, 300(1), 104-105. http://dx.doi.org/10.1038/scientificamerican0109-104. PMid:19186758.

Gawande, A. (2011). Checklist como fazer as coisas benfeitas (1. ed.). Rio de Janeiro: Sextante.

Marcelino, H. P., \& Weiss, J. M. G. (2009). Melhoria de processos por meio do mapeamento do fluxo de valor: estudo de caso. In Anais do XXIX Encontro Nacional de Engenharia de Produção. Rio de Janeiro: ABEPRO.

Marchwinski, C., \& Shook, J. (2011). Léxico Lean: glossário ilustrado para praticantes do Pensamento Lean (4. ed.). São Paulo: Lean Institute Brasil.

Maximiano, A. C. A. (1988). Aplicação do PMBOK a projetos acadêmicos. In Anais do III Seminário em Administração. São Paulo: FEA-USP. Retrieved in 2017, June 2, from http://www.ead.fea.usp.br/semead/3semead/

Miguel, P. A. C. (2007). Estudo de caso na engenharia de produção: estruturação e recomendações para sua condução. Produção, 17(1), 216-229. http://dx.doi.org/10.1590/S0103-65132007000100015.

Moreira, M. P., \& Fernandes, F. C. F. (2001). Avaliação do mapeamento do fluxo de valor como ferramenta da produção enxuta por meio de um estudo de caso. In Anais do XXI Encontro Nacional de Engenharia de Produção. Rio de Janeiro: ABEPRO.

Nonaka, I., \& Takeuchi, H. (1995). The knowledge-creating company: how Japanese companies create the dynamics of innovation (1. ed). Oxford: Oxford University Press.

Ohno, T. (1997). O Sistema Toyota de Produção (1. ed.). Porto Alegre: Bookman.

Park, S. T., \& Yang, B. S. (2010). An implementation of risk-based inspection for elevator maintenance. Journal of Mechanical Science and Technology, 24(12), 2367-2376. http://dx.doi.org/10.1007/s12206-010-1004-1.

Prates, C. C., \& Bandeira, D. L. (2011). Aumento de eficiência por meio do mapeamento do fluxo de produção e aplicação do Índice de Rendimento Operacional Global no processo produtivo de uma empresa de componentes eletrônicos. Gestão \& Produção, 18(4), 705718. http://dx.doi.org/10.1590/S0104-530X2011000400003.

Project Management Institute - PMI. (2013). A guide to the project management body of knowledge (5th ed.). Pennsylvania: PMI Publishing Division, Project Management Institute.

Rabechini Junior, R., Carvalho, M. M., Rodrigues, I., \& Sbragia, R. (2011). A organização da atividade de gerenciamento de projetos: os nexos com competências e estrutura. Gestão \& Produção, 18(2), 409-424. http://dx.doi.org/10.1590/S0104-530X2011000200014.

Rother, M., \& Shook, J. (2012). Aprendendo a enxergar: mapeando o fluxo de valor para eliminar o desperdício (2. ed.). São Paulo: Lean Institute Brasil. 
Salgado, E. G., Mello, C. H. P., Silva, C. E. S., Oliveira, E. S., \& Almeida, D. A. (2009). Análise da aplicação do mapeamento do fluxo de valor na identificação de desperdícios do processo de desenvolvimento de produtos. Gestão \& Produção, 16(3), 344-356. http://dx.doi.org/10.1590/S0104-530X2009000300003.

Schindler, A. (2018). Manual do transporte vertical. Switzerland. Retrieved in 2018, November 6 , from https://www.schindler.com/content/dam/web/br/PDFs/NI/manual-transportevertical.pdf

Shingo, S. (1996). O Sistema Toyota de Produção: do ponto de vista da Engenharia de Produção. Porto Alegre: Artmed.

Shook, J. (2009). Toyota's secret: the A3 report. MIT Sloan Management Review, 50(4), 30. http://dx.doi.org/10.1111/j.1540-4609.2011.00308.x.

Shook, J. (2014). Gerenciamento para o aprendizado: usando o processo de gestão A3 para resolver problemas, promover alinhamento, orientar e líder (2. ed.). São Paulo: Lean Institute Brasil.

Silva, D. A. R., Clemente, D. H., Terra, J. D. R., Lopes, K. M., Carvalho, M. M., Fleury, A. L., Zancul, E. S., \& Marx, R. (2017). Aspectos comportamentais na gestão de projetos: uma análise bibliométrica (1988-2014). Gestão \& Produção, 24(1), 178-200. http://dx.doi.org/10.1590/0104-530x2208-15.

Tetlow, K. (2007, september). New elevator technology: the machine room-less elevator. Construction. Retrieved in 2018, October 25, from https://www.construction.com/CE/articles/0709kone-7.asp

Thyssenkrupp Elevadores - ThyssenKrupp. (2018). Descritivo técnico - Grife One (sem casa de máquinas). Retrieved in 2018, November 6, from http://www.thyssenkruppelevadores.com.br/pt-BR/produto/cabina_one/

Valle, A. B., Soares, C. A. P., Finocchio Junior, J. F., \& Silva, L. S. F. (2010). Fundamentos do gerenciamento de projetos (2. ed.). Rio de Janeiro: FGV.

Vargas, R. V. (2007). Manual prático do plano de projeto: utilizando o PMBOK@ Guide (3. ed.). Rio de Janeiro: Brasport.

Womack, J. P., \& Jones, D. T. (1996). Lean thinking: banish waste and create wealth in your corporation. New York: Simon \& Schuster.

Womack, J. P., Jones, D. T., \& Roos, D. (1990). The machine that changed the world. New York: Rawson Associates.

Womack, J. P., Jones, D. T., \& Ross, D. (2004). A mentalidade enxuta nas empresas lean thinking: elimine o desperdício e crie riqueza. Rio de Janeiro: Elsevier.

Yin, R. K. (2015). Estudo de caso: planejamentos e métodos (5. ed.). Porto Alegre: Bookman. 


\section{Annexe A. Template A3.}

Template A3's left side - Planning and current state mapping.

\section{Context}

Enhancing productivity and quality, saving time and reducing costs on eletromechanical elevators without machine room installation that, consequently, affect other indicators and lead to success before the involved parties, as clients, shareholders and collaborators. This need comes from the raising competition on the market in the last few years, the current economic crisis and lower competitor's products prices.

The applied tools to reach the improvements are the best practices suggested in the PMBOK guide to project management and lean thinking applied to equipments and machines assembling.

\section{Current State - Agosto 2014}

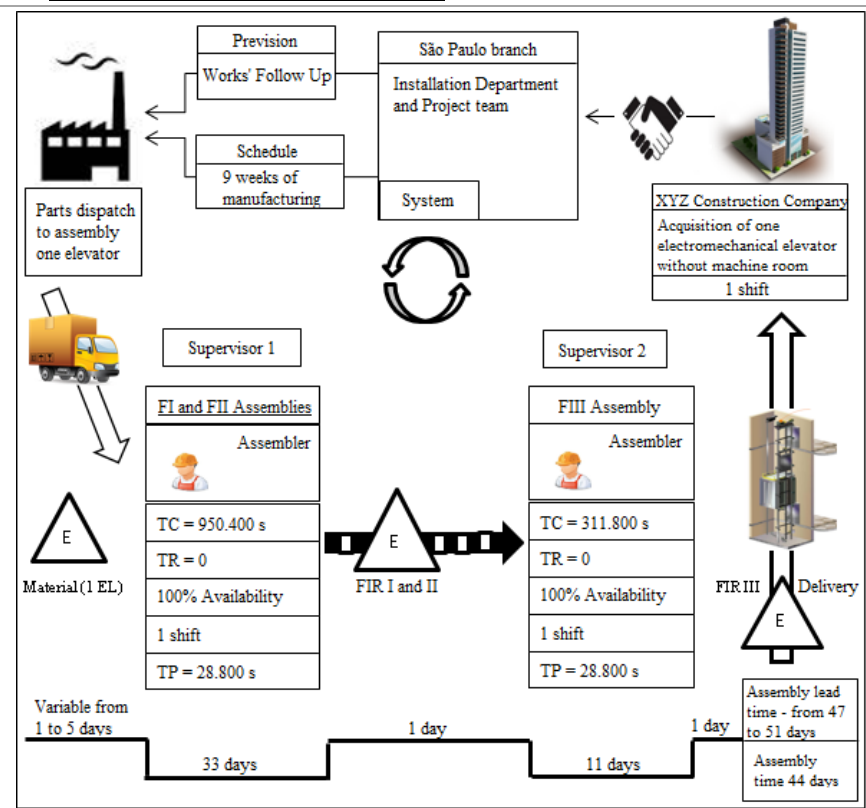

1.

1.

1.

1.

1.

1.

\section{Problems:}

$\rightarrow$ Lack of synchronism at equipment and material delivering to the installation site. Company's Material dispatch only happened twice a week; $\rightarrow$ Low qualification
installation team;

$\rightarrow$ Inadequate IRF I,II and III filling by the assemblers;

$\rightarrow$ Assembly and installation processes could be simplified by transferring some stages to pre installation;

$\rightarrow$ Replacement of missing or misguided parts took too long;

$\rightarrow$ Various problems regarding materials distribution at the installation site;

$\rightarrow$ There were quality issues at the installation conclusion, with reflex on the final installation quality and rework periods of time. 


\section{Goals/Objectives}

Reduce under $15 \%$ the time and installation costs, predicted in contract.

Deliver the final equipment without the quality issues marked at the delivery letter and with quality expected by the client.

4. Analysis - Elevators installation problems analysis by Ishikawa's.

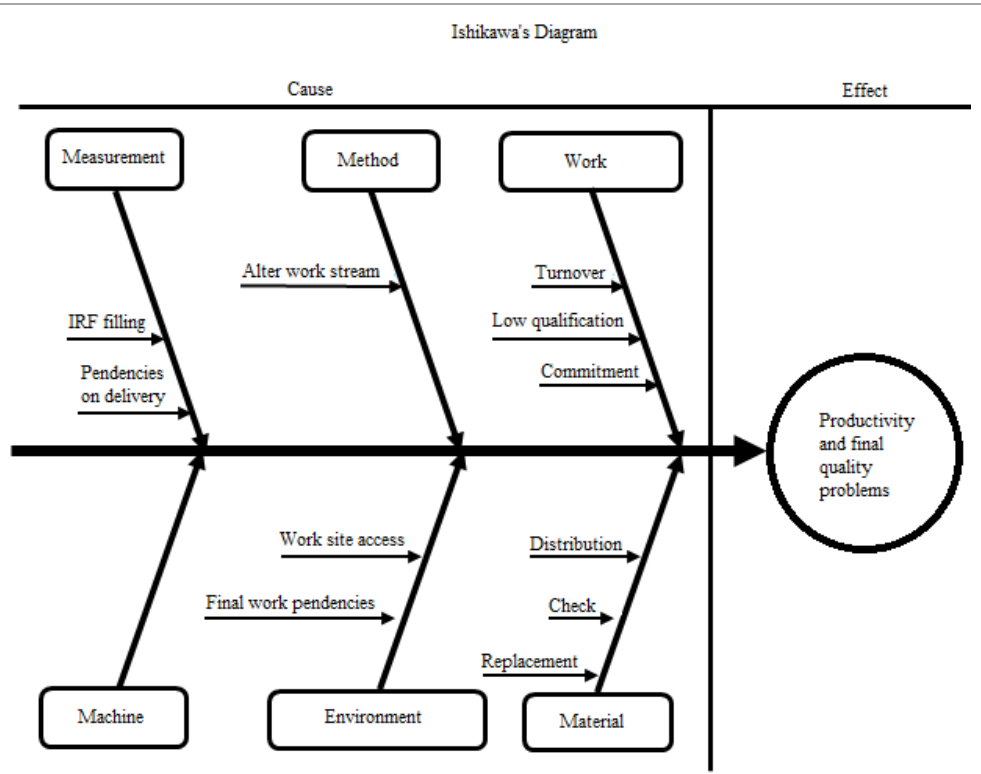

Template A3's left side - Execution, control, improvement actions and future state map.

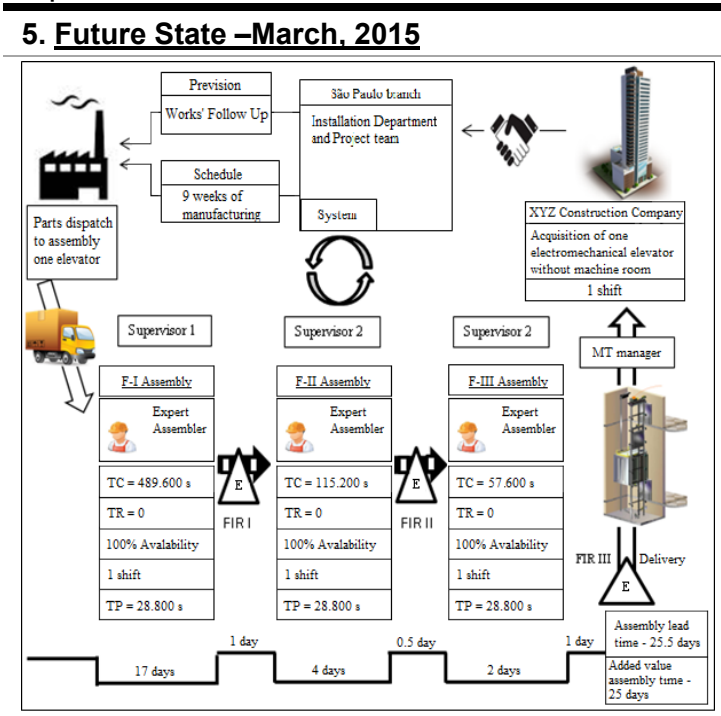

Improvements:

$\rightarrow$ Eliminate the material dispatch wait time by monitoring and controlling the company's expedition to the shipping company and construction responsible. Utilize daily components and materials transport from the parent company to the subsidiary company;

1.

$\rightarrow$ Allocate specialized and
experienced assemblers in all
elevators assembling and
installation stages. Designate a
categorized supervisor to perform
equipment final adjustments;


1.

$\rightarrow$ Allocate supervisors to accompany the installation full time and fill, mandatorily, the IRF I,II and III;

1.

$\rightarrow$ Transfer the distribution, materials conference and plummet lines installation to pre-installation (performed before elevator installation begins);

1.

$\rightarrow$ Apply the same installation process utilized by the company's high performance teams;

1.

$\rightarrow$ Check and distribute the materials and parts before starting installation;

1.

$\rightarrow$ Avoid misguided parts by installation site supervisor constant presence and quickly replace missing parts by project team's effective actions along the company;

6. Plane - Gantt chart detailing the equipment installation after process improvement:

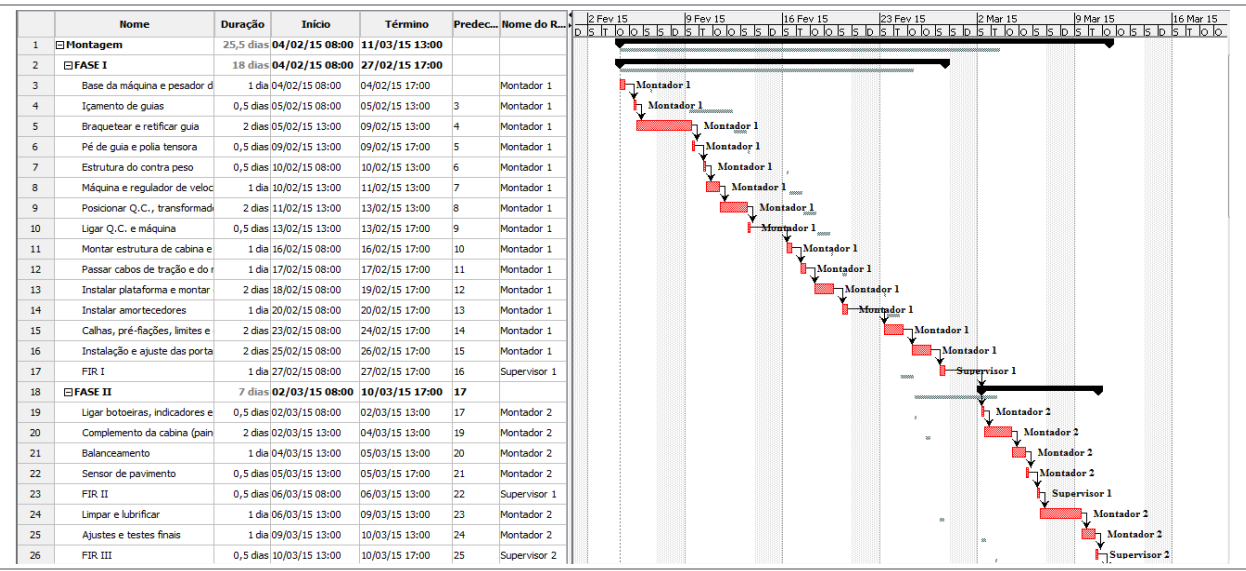

\section{Monitoring}

The PM team carried out weekly meetings with the supervisor. The supervisor visited the work site before installation beginning, at the stages I and II closure and product delivery. Performed daily follow up with the supervisor that was full time at the work site. Analyzed and monitored the installation schedule, the IRF I, II and III and the delivery letter signed by the client.

At previous and posterior analysis of the value-added time (VAT) and the lead time, comparing the current and future states, the gains can be observed.

This improvement process can be extended to various areas/stages and will be tested with other products at the department where the pilot test was performed. 